\title{
Effects of Culture and Gender in Comprehension of Speech Acts of Indirect Request
}

\author{
Rabe'a Shams \\ Akbar Afghari \\ Department of English, Khurasgan(Isfahan) Branche, Islamic Azad University, Isfahan, Iran \\ Tel: 98-74-2422-3522 E-mail: Rabi.shams@gmail.com
}

Received: May 30, 2011

doi:10.5539/elt.v4n4p279

\author{
Accepted: June 28, 2011 \\ Published: December 1, 2011 \\ URL: http://dx.doi.org/10.5539/elt.v4n4p279
}

\begin{abstract}
This study investigates the comprehension of indirect request speech act used by Iranian people in daily communication. The study is an attempt to find out whether different cultural backgrounds and the gender of the speakers affect the comprehension of the indirect request of speech act. The sample includes thirty males and females in Gachsaran(a city in the province of Kohgiloye va Boyerahmad in Iran) and thirty participants (males and females) in Farokhshahr(a city in the province of Chaharmahal va Bakhtiyari in Iran). A questionnaire is used to elicit data related to the responses used by each group. The questionnaire consists of twenty situations. The participants write their reaction to each situation. The results reveal that culture has significant effect on the interpretation of indirect request of speech act. But gender doesn't affect the comprehension of indirect request of speech act.
\end{abstract}

Keywords: Cultural differences, Indirectness, Pragmatics, Request speech act, Speech acts (SA)

\section{Introduction}

According to Mey (1998) language is an inseparable part of our daily life. It is a tool used to transmit messages and to communicate ideas, thoughts, and opinions. It is because of language that human being is situated in the society; language is a social phenomenon which creates and determines our position in different kinds of social networks and institutions. Culture is communication, and vice versa because it influences social practices in general, and discourse in particular. Moreover, cultural factors play an important role in the development of diverse ways of talking and communicating. It can be said that there exists a certain, rule-governed linguistic behavior such as thanking, requesting and apologizing that allows us to deal with similar situations in similar ways across cultures (Mey, 1998).

People do not produce the grammatical utterances and words merely to express themselves; they perform actions via these utterances. Semanticists and pragmatists have scrutinized different interpretations and uses of language. For example, Koike (1989, p. 279) defines pragmatic competence as "the speaker's knowledge and use of rules of appropriateness and politeness which indicate the way the speaker will understand and formulate speech acts (SAs)." Obviously, communicative acts or SAs are among the most attractive areas in pragmatics and sociolinguistics.

SAs are defined as acts performed by the speaker while making an utterance. The theory of SAs is a theory about what people set out to accomplish when they choose to speak. Searl (1975), the American language philosopher, believed that all linguistic communication involves linguistic SAs. According to Searl (1975) a language is performing SAs such as making statement, giving command, asking question or making promises. Searle's approach holds that SAs are only explained by special conventions that are neither semantic nor pragmatic (in the sense of Grice's maxims of conversation).

Austin (1962) also studied the issue of SAs. He pointed out that people use language to achieve certain kinds of acts generally recognized as SAs which are distinct from physical acts like drinking or mental acts like thinking. SAs are divided into 'direct' and 'indirect' SAs. Searle (1975) developed the idea of indirect SAs, where one SA is performed via another, e.g., an utterance functioning as a statement on the surface can have an underlying function of requesting in a given context. Austin (1962) introduced basic terms to study and distinguish locutionary, illocutionary, and perlocutionary acts. These three types of acts play an important role in understanding and investigating direct and indirect SAs. In standard speech act account (Levinson, 1983), indirectness of SAs occurs when a speaker uses an illocutionary force to indicate a different illocutionary force than the one intended. Searle (1975) argued that what speakers try to communicate is their intention to do something. 
Evidently, understanding the motives behind utterances is often crucial to successful communication; nevertheless the relationship between the surface of an utterance and its underlying meaning is not always straightforward.

Request is one type of SAs. A request is a speech act which expresses the speaker's desire for the hearer to perform an action with the added proviso that the hearer takes this expressed desire as the reason to act (Bach \& Harnish, 1979). In fact, requests are performed by the speaker expressing for the addressee to do a particular thing and usually aim for the addressee to intend to do it. Requesting occurs when the speaker's utterance has the function of attempting to obtain a specific piece of information. It is interesting to know that conventional indirect request may be expressed as a question or an assertion. Wh-questions and how-questions are therefore considered as requesting rather than questioning because they seek to obtain information rather than clarification.

The speakers and hearers must consider the context in which the SAs are uttered. Here, felicity conditions are very important in order to "do thing with words" (Searl, 1975). It should be noted that in order for the SAs to be uttered, certain conditions must be met. For example, in a context, sometimes an indirect request may be immediately understood as a complaint. So, in this kind of indirect SAs, the listener must understand the exact meaning and speaker's intention to respond. Brown and Levinson (1987) argue that direct requests appear to be inherently impolite and face-threatening because they intrude in the addressee's territory. They point out that the preference for polite behavior is its indirectness (see also Leech, 1983).

So the purpose of this research is to investigate the effect of gender on perception of indirect request of speech act. Another objective of this study is to investigate if culture makes a statistically significant difference in understanding the indirect request of speech act Therefore; the following research questions were posed:

1. Does culture affect the perception of the speech acts of indirect request?

2. Does gender affect the interpretation of the speech acts of indirect request?

Based on the above research questions, the following hypotheses were formulated:

1. Culture has no effect on the comprehension of the speech act of indirect request.

2. Gender has no effect on the comprehension of the speech act of indirect request in different cultures.

\section{Review of the Literature}

A speech act is an action performed by means of language. We perform SAs when we offer an apology, a greeting, a request, a complaint, an invitation, a compliment, or a refusal (Austin, 1962; Searle, 1969).

There are many utterances with the purpose of affecting the hearer in one way or another; some convey the information directly, others are more careful or polite, and they use indirectness to transmit the message. Indirectness is a widely used conversational strategy. People tend to use indirect SAs mainly in connection with politeness (Leech, 1983, p. 108) since they thus diminish the unpleasant message contained in requests and orders for instance. Politeness is not the only motivation for indirectness. "People also use indirect strategies when they want to make their speech more interesting, when they want to reach goals different from their partners or when they want to increase the force of the message communicated" (Thomas, 1983, p. 143).

Requests are directed towards a listener to portray a speaker's desire and intent for the listener to fulfill this desire by offering information or action. There are two main types of requests: direct and indirect (Tsui, 1996, as cited in Irawati, 2009). Direct requests, or imperatives, explicitly state the desired action, whereas indirect requests implicitly state the desired action. There are several types of indirect requests: embedded imperatives- an action is explicitly stated, question directives implicitly mention the desired action in question format need/want statementsstated in terms of the speaker's desires hints- and request a desired action in a hidden manner; suggestions- specify that the speaker will join the listener in the desired action; and questions -request a desired action explicitly in a questioning manner with questioning intonation which rises at the end (Irawati, 2009).

Among the numerous SAs studied, requesting has continually been the focus for many decades because of both the complexity of the relationship among form, meaning, and pragmatics in requests, and the high social stakes involved for interlocutors when choosing among linguistic options ( Márquez - Réiter , 2002 ; Wierbzicka , 2003 ; Irawati , 2009 ). Zhang (1995) categorized requests in Chinese into two types: direct and indirect. Even direct one can be viewed at different direct levels. She described indirectness in modern conversations between Chinese as being "associated with information sequencing. The more one beats around the bush, the more indirect one's speech becomes" (1995, p. 82). Zhang's study focused on the strategies used by adult speakers driven by politeness concerns in order to redress face. She claimed that in Chinese culture, requests are often regarded as signs of a good relationship and even respect.

Actually, the universality of an SA does not necessarily suggest a similarity in the form used to express the same SA. 
For example, making the request in English is different from doing it in Persian. Requests have been mostly investigated in the field of cross-cultural pragmatics (Deutschmann, 2003) to compare the use of request SA between native English speakers and native speakers of other languages like Chinese (Sheer \&Chen, 2003), Arabic (Al-khateb, 2009), and Persian (Jalilifar, 2009).

Classical SAs theory defined apologizing and requesting as a culture-sensitive 'speech-act set' (Olshtain \& Cohen, 1983) of semantic formulae or strategies being relevant to a felicitous performance of these two kinds of SAs. Such a model was proposed by Cohen and Olshtain (1981) (derived from Fraser, 1981) and later developed (both for apologies and requests) by Blum-Kulka and Olshtain (1984) and by Blum-Kulka et al. (1989) into the CCSARP (Cross-cultural study of SA realization patterns) project. Most of these cross-cultural studies have been carried out within CCSARP project "to compare across languages the realization patterns of two SAs- requests and apologiesand to establish the similarities and differences between native and nonnative speakers' realization patterns in these two acts" (Blum-Kulka \& Olshtain, 1984, p. 196).

Gender affects the perception of direct and indirect SAs. Several studies suggest that females are prone to produce indirect SAs and males direct (Mckelvie, 2000; Mulac, Bradac, \& Gibbons, 2001). These studies have examined how different genders comprehend indirect SAs. Tannen (1994) has compared gender differences in language as more similar to 'cultural' differences ("cultural difference approach"). Comparing conversational goals, she argued that men have a report style, aiming to communicate factual information, whereas women have a rapport style, more concerned with building and maintaining relationships. Such differences are pervasive across media, including face-to-face conversation. Communication styles are always a product of context, and as such, gender differences tend to be most pronounced in single-gender groups. One explanation for this is that people accommodate their language towards the style of the person they are interacting with. An important observation is that this accommodation is usually towards the language style, not the gender of the person. That is, a polite and empathic male will tend to be warmed up to on the basis of their being polite and empathic, rather than their being male.

\section{Methodology}

\subsection{Participants}

At the beginning of the study, the participants in this study were 60 randomly-selected ordinary people who were selected from different social classes with different educational levels. Oxford Placement Test was used to select participants (OPT).Since the objectives of this study were first to compare gender and then cultures, 30 males and 30 females were selected. Of these 60 people 15 males and 15 females were from Gachsaran, a city in Kohgiloye va Boyerahmad Province, their native language is Turkish, and 15 males and 15 females were from Farokhshahr, a city in the Province of Chaharmahal va Bakhtiyari, their native language is Farsi. Their age ranged between 19 and 26. Then they were divided into four groups as follows: Group 1, 15 females from Gachsaran; Group 2, 15 Males from Gachsaran; Group 3, 15 females from Farokhshahr; and Group 4, 15 males from Farokhshahr. After collecting the questionnaires it was found out that only 55 people completed them: 14 females from Gachsaran, 13 females from Farokhshahr, 13 males from Gachsaran, and 15 males from Farokhshahr.

\subsection{Materials}

The materials for this study consisted of a questionnaire in Farsi which included 20 items. The questionnaire was prepared in Farsi because the main factor of the study was culture not his or her language and the researcher wanted to make the same situation for all participants. All Turkish participants can speak Farsi and Turkish but the participants of Farokhshahr can speak only Farsi. All these items prompted an indirect request which had to be provided by the respondents. In the questionnaire a situation was briefly described in which an indirect request was implied, and the respondents were expected to understand the request and provide the best answers for the situations.

The instruction of the questionnaire asked the respondents (in Farsi) to read the situations carefully and write down the action which comes to their mind for each item.

\subsection{Reliability and validity of the study}

The researcher used the questionnaire of the study after showing it to four instructors at Azad University of Khourasgan, and two experienced English teachers. They suggested some changes on some of the items in the questionnaire. For example, the situation of each item must be described exactly that the participants comprehend each situation correctly. According to their suggestions some items were added and some of them omitted

\subsection{Procedures}

In order to gather the necessary information, a questionnaire with 20 situations was prepared. Then 60 copies of the 
questionnaires were distributed among the randomly selected ordinary people to fill. They were given the necessary information regarding the reason and the way to fill them; they were given half a day to complete the questionnaire; in other words, the questionnaires were distributed in the morning and were collected in the afternoon. The reason for this was that some of them were busy doing their work and needed some free time to do the task; therefore, this researcher decided to let them fill the questionnaires during their lunch break.

The data obtained from the questionnaire were quantified. After the questionnaires were collected; the answers were analyzed and the degree of frequency of each group was measured. The degree of frequency regarding to the age and culture of participants was measured.

\subsection{Statistical procedures}

To compare the results of different groups with each other, by using SPSS software, the degree of frequency was measured and Chi-square test was calculated. There were four groups involved in the study and two independent variables, namely, gender and culture.

\section{Results}

\subsection{Testing the first hypothesis}

In order to test the first hypothesis, which tried to find out cultural differences regarding indirect request, 55 questionnaires were gathered, 27 participants (both male and female) from Gachsaran and 28 participants (both male and female) from Farokhshahr answered the items on the questionnaires. The degree of frequency of each group was calculated. Table 1 presents the degree of frequency in interpretation of indirect request of SA in two different cities. Figure 1 illustrates the frequency graphically.

By referring to Table 1 one can see that the rate of frequency of the two cultures is different. In order to find out whether this difference is statistically significant or not the Chi-Square test was used. Table 2 reveals the results of the Chi-Square tests.

As it is clear in Table 2 the amount of Chi-Square in the test is low enough, that is, smaller than the statistical scale at significance level of $.05(\alpha=0.05)$. The level of significance in this test is .001 , which is lower than 0.05 . In other words, the difference between the two cultures under investigation is statistically significant. Therefore, the first hypothesis stating that culture has no effect on comprehension of the $S A$ of indirect request is rejected, and it can be claimed that culture has a significant effect on comprehending the SA of indirect request. According to the analyzed data, the degree of politeness of participants showed that the participants of Gachsaran responded more politely than the participants of Farokhshahr. So we can say the culture has an effect on comprehension of indirect request of SA, and the reactions of participants in different situations differ based in their cultures.

\subsection{Testing the second hypothesis}

The number of the participants for gender was 27 for females and 28 for males. Table 3 shows the degree of frequency in interpretation of indirect request of SA according to the gender of participants.

As can be seen in Table 3 and Figure 2 that the degrees of frequency of the two groups are not very different. In order to understand if this difference is statistically significant or not, the Chi-Square tests were used. Table 4, shows the results of Chi-Square tests.

According to Table 4, the number obtained by the amount of Chi-Square is not high enough to be considered significant. In other words, it is only significant at the significance level of .789 which is higher than the agreed significance level of .05 . Therefore, the second hypothesis which stated that gender has no effect on the comprehension of the $S A$ of indirect request in different cultures is retained. It means that gender does not have any effect on comprehending the SA of indirect request. As data show, females were more polite than males in the two different cities. According to Figure 2 females' responses in Gachsaran were more polite than those of females who lived in Farokhshahr.

All in all, with regard to the findings of this study the first hypotheses was rejected, but the second hypothesis was supported.

\section{Discussion of the Findings}

\subsection{Discussing the findings related to the first question}

It is obvious from the statistical analysis that there are significant statistical differences between the comprehensions of indirect SA of request in the two different cultures. In other words culture has significant effect on the comprehension of the SA of indirect request. The collected responses from the two different cities (Farokhshahr and Ghachsaran) were very different. That is, each group gave the different responses to the set situations. Varieties of a 
language and sociocultural parameters make differences in language use. As the researcher mentioned, the languages of the participants were not the same. The participants of Gachsaran speak Turkish and the participants of Farokhshahr speak Farsi. So their languages had effect on the reaction and comprehension of the SA of indirect request. According to the findings of this research, the cultural norms and the accent of participants were considered as an important factor to interpret the indirect request. This study was done in one and the same country and the cultures of the cities had significant effect on the perception of illocutionary act. The findings of this study support the results of some cross-cultural studies in the field of SA (e.g., Beebe, Takahashi \& Uliss-Weltz, 1990; Bergman \& Kasper, 1993; Blum-Kulka,1989; Cohen \& Olshtain, 1981; DeCapua, 1989; Garcia, 1989; (Olshtain \& Cohen, 1983); Takahashi \& Beebe, 1993; Takahashi \& Dufon, 1989; Trosborg, 1987). They show the great importance and influence of the pragmatic knowledge related to the social and cultural styles and norms. Kachru(1998), in an empirical study, showed that sociocultural factors have significant effect on the choice of request strategies by Indian and Singaporean subjects. All findings of the above research support the findings of the current study.

\subsection{Discussing the findings related to the second question}

According to the obtained data, there was no significant statistical difference on the comprehension of SA of indirect request between the two genders. In other words, no statistically significant differences were seen in the interpretation of indirect request of SA between males and females. Accordingly, the second hypothesis of the research is also retained.

As the results show, all the participants (males and females) regardless of their cultures did comprehend the indirect request .They understood the exact meaning of the requestor but their responses were different from one another. One criterion was the degree of politeness. The findings of this study represented that females were more polite than males.

Several studies have examined the effect of gender on the use of direct or indirect SA of request. The results of those studies show that females are more prone to producing indirect request and males direct (Mulac, Bradac, \& Gibbons, 2001; Mckelvie, 2000; Macaulay, 2001). The findings of those studies represented the effect of gender on the use of direct or indirect request speech. The current study examined the effect of gender on the comprehension of SA of indirect request and the results were in contrast with the study done by Champagne (2001). He suggested that comprehension of indirect request is more difficult to interpret than other kinds of speech (Champagne, 2001).

\section{Conclusion}

People are well aware of the fact that some, mostly negative, information cannot or should not be expressed explicitly or directly and that indirect strategies should be applied for successful communication. Indirectness nowadays plays a vital role in our communication. On the other hand, the use of language is so closely and uniquely tied to culture, and often rules of speaking vary across cultures. This study was designed to address the important issue of pragmatic development of indirect request in Iranian communication in order to determine whether and to what extent the culture and gender of the participants affect the comprehension of SA of the indirect request.

It seems that the Iranian participants in this study try to use indirect request rather than direct form (regardless of culture). This supports Brown and Levinson's (1978) Politeness Theory: people tend to choose indirect forms over direct ones to show politeness since being direct is face-threatening.

The present study suggests the importance of reexamining stereotypes and reconsidering conventional models of linguistic SA as indirect request. Findings show that people with different cultural backgrounds usually tend to express their requests indirectly. The requester demands his or her request indirectly and the addressee comprehends it correctly.

\section{Implications of the Study}

It is hoped that this study can provide some real-life examples in Iran, as well as data to researchers in pragmatics. The appropriate use of language is very important in daily communication, and a listener should understand the exact meaning of a speaker to make successful communication. The current study is helpful in all conversations to achieve the correct message of the speakers. Today most utterances serve to express propositions and to perform actions. Every utterance has an illocutionary force (performs a SA); it brings about a context change. The illocutionary force of an utterance is determined not by form alone but by a complex interaction between form and context. So, studying comprehension of illocutionary force plays an important role in linguistic competence and performance. The results of this study provide the pragmatic model for linguists.

The theoretical implications of the study help in discourse analysis between two different cultures. This study has provided the practical usage in linguistic field especially in SA. The comprehension of indirect request is useful for second language learners so this research provides helpful assistance in teaching. 
This study could be especially helpful for teachers of foreign or second languages as it further supports the idea that language, particularly SAs, is laden with culture. SAs include real-life interactions and require not only knowledge of the language but also appropriate use of that language within a given culture.

\section{Suggestions for Further Studies}

This study provides grounding for information regarding the influence of social power, age or social distance on the use of SAs can be investigated between Persian and English. Comparative-contrastive studies can be conducted to investigate the use of various SAs, such as requests, refusals, promises, apologies etc. between the two above-mentioned languages. Different variables such as age, education and social class can be considered to investigate the comprehension of indirect request of SA in further researches. It is recommended that future studies examine the language use in children's interactions or child-adult interactions.

\section{References}

Al-Khateeb, M. (2009). The speech act of thanking as a compliment response as used by the Arab speakers of English a comparative intercultural study. Palestine: An-Najah National University.

Austin, J. L. (1962). How to do things with words. Oxford: Oxford University Press.

Bach, K., \& Harnish R. M. (1979). Linguistic communication and speech acts. Cambridge, MA: MIT Press.

Beebe, L., Takahashi, T., \& Uliss-Weltz, R. (1990). Pragmatic transfer in ESL refusals. In R. Scarcella, E. Andersen, $\&$ S. Krashen (Eds.), On the development of communicative competence in a second language. New York: Newbury House.

Bergman, M., \& Kasper, G. (1993). Perception and performance in native and nonnative apology. In G. Kasper \& S. Blum-Kulka (Eds.), Interlanguage pragmatics. New York: Oxford University Press.

Blum-Kulka, S., House, J., \& Kasper, G. (1989). Investigating crosscultural pragmatics: an introductory overview. In S. Blum-Kulka, J. House, \& G. Kasper (Eds.), Cross- cultural pragmatics: requests and apologies. Norwood. NJ: Ablex.

Blum-Kulka, S., \& Olshtain, E. (1984). Requests and apologies: A cross-cultural study of speech-act realization patterns (CCSARP). Applied Linguistics 5, 196-213. http://dx.doi.org/10.1093/applin/5.3.196

Brown, P., \& Levinson, S. C. (1987). Politeness: Some universals in language usage. Cambridge: Cambridge University Press.

Champagne, M. (2001). Comprehension of no literal discourse: the case of violations of the maxims of quantity and indirect request. Rsicologia: Reelexao e Critica, 14, 379-385

Clark, H. H. (1979). Responding to indirect speech acts. Journal of Cognitive Psychology, 11, 430-477. http://dx.doi.org/10.1016/0010-0285(79)90020-3

Cohen, A. D., \& Olshtain, E. (1981). Developing a measure of socio-cultural competence: The case of apology. Language Learning, 31, 113-134. http://dx.doi.org/10.1111/j.1467-1770.1981.tb01375.x

DeCapua, A. (1989). An analysis of pragmatic transfer in the speech act of complaints as produced by native speakers of German and English. Unpublished doctoral dissertation. Columbia University.

Deutschmann, M. (2003). Apologizing in British English. Sweden: Tryckt av Print, Umea University.

Fraser, B. (1981). On apologizing. In F. Coulmas (Ed.), Conversational routines. Mouton de Gruyter: The Hague. pp. $259-271$

Garcia, C. (1989). Apologizing in English. Politeness strategies used by native and nonnative speakers. Multilingua, 8, 3-20. http://dx.doi.org/10.1515/mult.1989.8.1.3

Irawati, R. (2009). Pragmatic analysis of request strategies in the novel the glass house. L. Bushell. Surakarta: University Of Surakarta.

Jalilifar, A. (2009). Cross-sectional study of Iranian EFL learners and Australian native speakers. English Language Teaching Journal. [Online] Available: www.ccsenet.org/uournal.html

Kachru, Y. (1998). Culture and speech acts: Evidence from Indian and Singaporean English. Studies in the Linguistic Sciences, 28 (1), 79-98

Koike, D. A. (1989). Pragmatic competence and adult L2 acquisition: Speech acts in interlaguage. The Modern Language Journal, 73, 279-289. http://dx.doi.org/10.2307/327002

Leech, G. (1983). Principles of pragmatics. London: Longman. 
Levinson, S. (1983). Pragmatics. Cambridge: Cambridge University Press.

Macualay, M. (2001). Tough talk: Indirectness and gender in requests for information. Journal of Pragmatics, 33, 293-316. http://dx.doi.org/10.1016/S0378-2166(99)00129-0

Márquez-Reiter, R. (2002). A contrastive study of conventional indirectness in Spanish: Evidence from Peninsular and Uruguayan Spanish. Pragmatics, 12(2), 135-151

Mckelvie, B. (2000). The effect of hyper femininity on communication patterns in dating couples. Dissertation Abstract International, 60, 63-75

Mey, J. L. (1998). Pragmatics: An Introduction. Oxford UK and Cambridge USA: Blackwell Publishers.

Mulac, Brada, \& Gibbons. (2001). Empirical support for the gender-as-a-culture hypothesis: An intercultural analysis of male/female language differences. Human Communication Research, 27, 121-152. http://dx.doi.org/10.1093/hcr/27.1.121

Olshtain, E., \& Cohen, A. D. (1983). Apology: A speech act set. In N. Wolfson \& E. Judd (Eds.), Sociolinguistics and language acquisition. Rowley, MA: Newbury. pp. 18-35

Searle, J. R. (1965). What is a speech act? In M. Black (Ed.), Philosophy in America. Ithaca, NY: Cornell University Press.

Searle, J. R. (1969). Speech acts: An essay in the philosophy of language. Cambridge: Cambridge University Press.

Searle, J. R. (1975). A taxonomy of illocutionary acts. In K. Gunderson (Ed.), Language, mind and knowledge .University of Minnesota press.

Sheer, V. C., \& Chen, L. (2003). Successful Sino-Western business negotiation: Participants' accounts of national and professional cultures. The Journal of Business Communication, 40(1), 50-85. http://dx.doi.org/10.1177/002194360304000104

Takahashi, T., \& Beebe, L. M. (1993). Cross-linguistic influence in the speech act of correction. In G. Kasper \& S. Blum-Kulka (Eds.), Interlanguage pragmatics. New York: Oxford University Press.

Takahashi, S., \& Dufon, M. A. (1989). Cross-linguistic influence in indirectness: the case of English directives performed by native Japanese speakers. Unpublished paper. University of Hawaii at Monoa.

Tannen, D. (1994). Gender and discourse. New York: Oxford University Press.

Thomas, J. (1983). Cross-cultural pragmatic failure. Applied Linguistics, 4(2), 91-112. http://dx.doi.org/10.1093/applin/4.2.91

Trosborg, A. (1987). Usage studies in interactional sociolinguistics. Cambridge: Cambridge University Press.

Wierzbicka, A. (2003). Cross-cultural pragmatics: The semantics of human interaction. Second edition. Berlin: Mouton de Gruyter.

Zhang, Y. (1995). Indirectness in Chinese requesting. In G. Kasper (Ed.), Pragmatics of Chinese as native and target language. Honolulu, HI: University of Hawaii Press. pp. 69-118

Table 1. Degree of Frequency Regarding Culture

\begin{tabular}{|l|c|c|c|}
\hline \multirow{2}{*}{} & \multicolumn{2}{|c|}{ Culture } & \multirow{2}{*}{ Total } \\
\cline { 2 - 3 } & Gachsaran & Farokhshahr & \\
\hline Correcr & 436 & 393 & 829 \\
\hline Incorrect & 118 & 167 & 285 \\
\hline Total & 554 & 560 & 1114 \\
\hline
\end{tabular}


Table 2. Chi-Square Tests for Culture

\begin{tabular}{|c|c|c|c|c|c|}
\hline & value & d.f & $\begin{array}{l}\text { Asymp. Sig. } \\
\text { (2-sided) }\end{array}$ & $\begin{array}{l}\text { Exact Sig. } \\
\text { sided })\end{array}$ & $\begin{array}{l}\text { Exact Sig. } \\
\text { sided })\end{array}$ \\
\hline $\begin{array}{l}\text { Pearson Chi- } \\
\text { Square }\end{array}$ & 10.623 & 1 & .001 & & \\
\hline $\begin{array}{l}\text { Continuity } \\
\text { Correction }\end{array}$ & 10.180 & 1 & .001 & & \\
\hline Likelihood Ratio & 10.666 & 1 & .001 & & \\
\hline Fisher'sExact Test & & & & 0.001 & 0.001 \\
\hline $\begin{array}{l}\text { Linear-by- Linear } \\
\text { Association }\end{array}$ & 10.613 & 1 & 0.001 & & \\
\hline $\mathrm{N}$ of Valid Cases & 1114 & & & & \\
\hline \multicolumn{6}{|c|}{ a. 0 cells $(.0 \%)$ have expected count less than 5 . The minimum expected count is 141.73 . } \\
\hline b. Computed only & a $2 \times 2 t$ & & & & \\
\hline
\end{tabular}

Table 3. Degree of Frequency Rrgarding Gender

\begin{tabular}{|l|c|c|c|}
\hline \multirow{2}{*}{} & \multicolumn{2}{|c|}{ Gender } & \multirow{2}{*}{ Total } \\
\cline { 2 - 3 } & Female & Male & \\
\hline Correct & 422 & 407 & 829 \\
\hline Incorrect & 153 & 153 & 309 \\
\hline Total & 575 & 560 & 1135 \\
\hline
\end{tabular}

Table 4. Chi-Square tests for Gender

\begin{tabular}{|c|c|c|c|c|c|}
\hline & value & d.f & $\begin{array}{c}\text { Asymp. Sig. } \\
\text { (2-sided) }\end{array}$ & $\begin{array}{c}\text { Exact Sig. (2- } \\
\text { sided) }\end{array}$ & $\begin{array}{c}\text { Exact Sig. (1- } \\
\text { sided) }\end{array}$ \\
\hline Pearson Chi-Square & $.073^{\mathrm{a}}$ & 1 & .787 & & \\
\hline $\begin{array}{l}\text { Continuity } \\
\text { Correction }^{\mathrm{b}}\end{array}$ & .041 & 1 & .839 & & \\
\hline Likelihood Ratio & 0.73 & 1 & .787 & & \\
\hline $\begin{array}{l}\text { Fisher exact Test } \\
\text { Linear -by -Linear } \\
\text { Association }\end{array}$ & 0.73 & 1 & 0787 & .789 & .419 \\
\hline $\mathrm{N}$ of Valid Cases & 1135 & & & & \\
\hline \multicolumn{6}{|c|}{ a. 0 cells $(.0 \%)$ have expected count less than 5 . The minimum expected count is 150.98 . } \\
\hline b. Computed only for & $2 \times 2$ tal & & & & \\
\hline
\end{tabular}




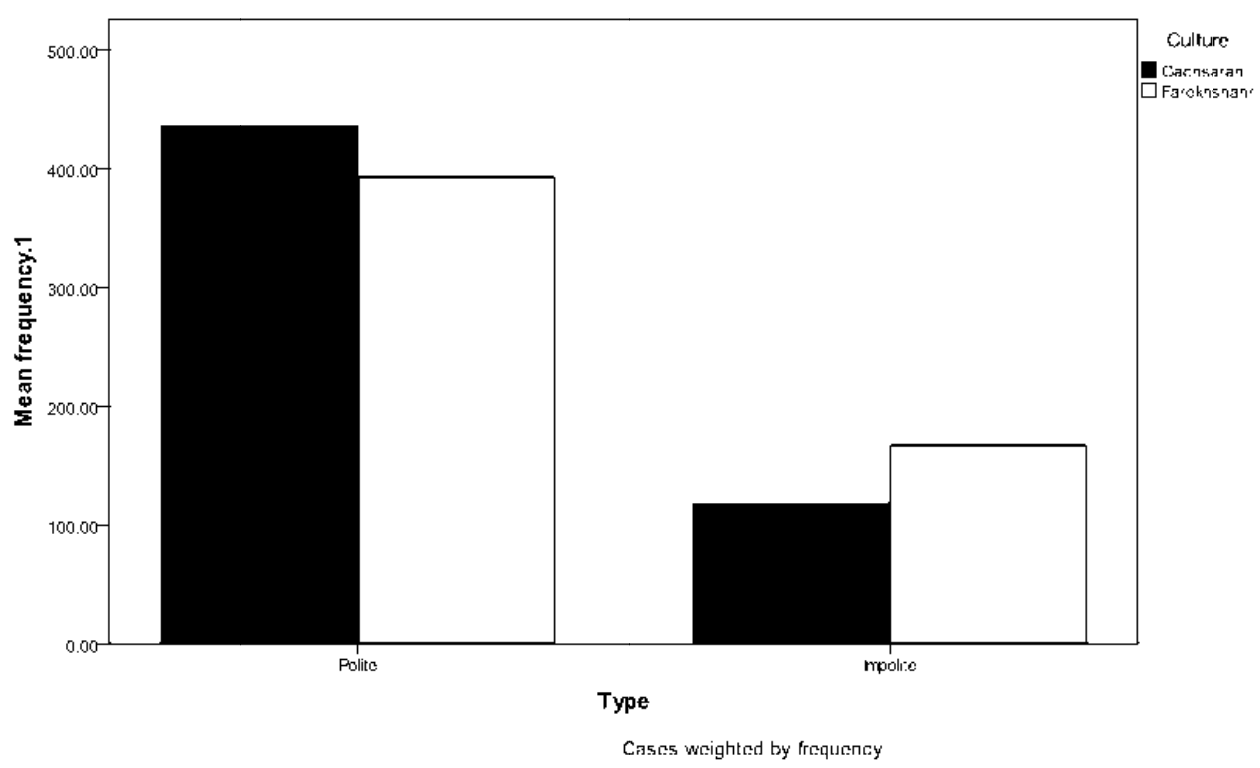

Figure 1. Graphical Representation of the Degree of Frequency for Culture

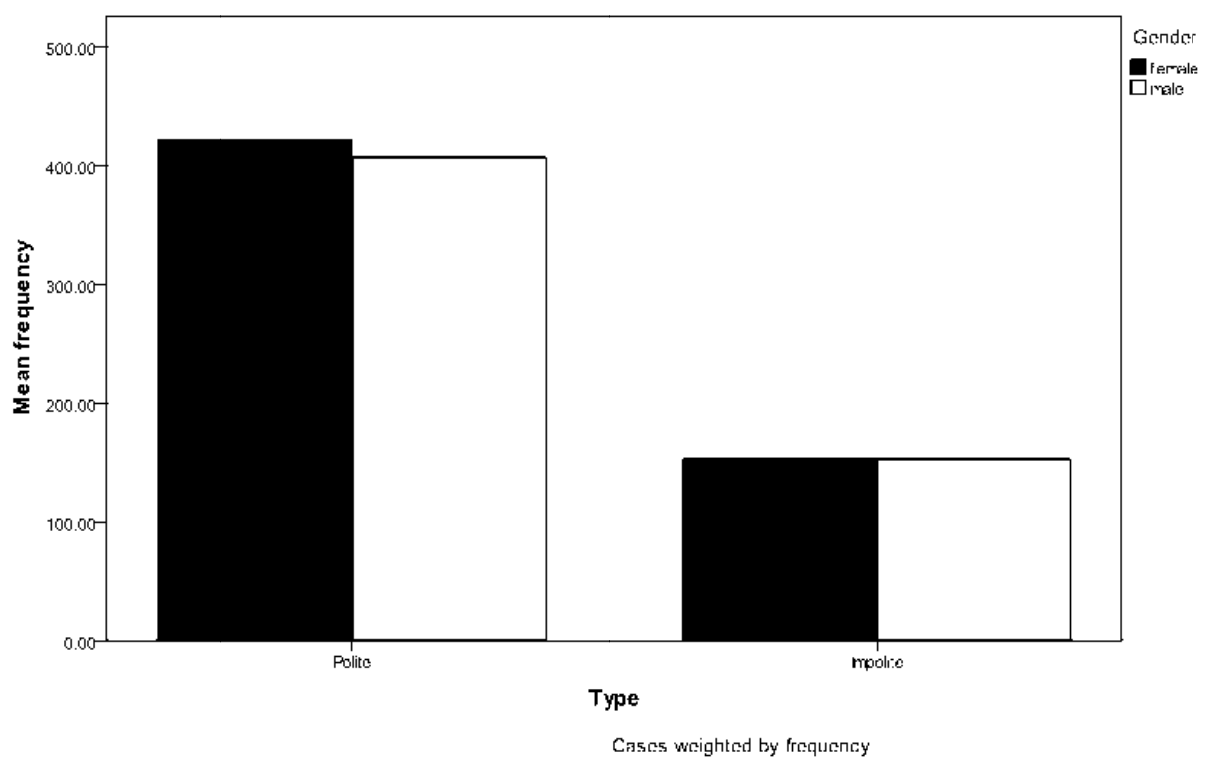

Figure 2. Graphical Representation of the Degree of Frequency for Gender 